6. Odelin MF, Pozzetto B, Aymard M, Defayolle M, Jolly-Million J. Role of influenza vaccination in the elderly during an epidemic of $A / H 1 N 1$ virus in 1988-1989: clinical and serological data. Gerontology 1993;39:109-116.

7. Meiklejohn G, Hoffman R, Graves P. Effectiveness of influenza vaccine when given during an outbreak of influenza A/H3N2 in a nursing home. J Am Geriatr Soc 1989;37:407-410.

8. Libow LS, Neufeld RR, Olson E, Breuer B, Starer P. Sequential outbreak of influenza A and B in a nursing home: efficacy of vaccine and amantadine. J Am Geriatr Soc 1996;44:1153-1157.

9. Foster DA, Talsma A, Furumoto-Dawson A, Ohmit SE, Margulies JR, Arden $\mathrm{NH}$, et al. Influenza vaccine effectiveness in preventing hospital ization for pneumonia in the elderly. Am J Epidemiol 1992;136:296-307.

10. Yassi A, McGill M, Holton D, Nicolle L. Morbidity, cost and role of health care worker transmission in an influenza outbreak in a tertiary care hospital. Canadian Journal of Infectious Diseases 1993;4:52-56.

11. Coles FB, Balzano GJ, Morse DL. An outbreak of influenza A (H3N2) in a well immunized nursing home population. $J \mathrm{Am}$ Geriatr Soc 1992;40:589-592.

12. Mukerjee A. Spread of influenza: a study of risk factors in homes for the elderly in Wales. J Epidemiol Community Health 1994;48:602-603.

13. Potter J, Stott DJ, Roberts MA, Elder AG, O'Donnell B, Knight PV, et al Influenza vaccination of health care workers in long-term-care hospitals reduces the mortality of elderly patients. J Infect Dis 1997;175:1-6.

14. Canadian consensus conference on influenza. Canadian Journal of Infectious Diseases 1993;4:251-256.

15. US Department of Health and Human Services. Healthy People 2000: National Health Promotion and Disease Prevention Objectives. DHHS publication no. PHS 91-50213. Washington, DC: Government Printing Office; 1991.

16. Siewert $M$, Drinka $P$, Langer $E$. High rates of immunization in a nursing home. Am J Infect Control 1988;16:228-230.

17. Nichol KL, Grimm MB, Peterson DC. Immunizations in long-term care facilities: policies and practice. J Am Geriatr Soc 1996;44:349-355.

18. DeWals $P$, Carbonneau M, Payette $H$, Niyonsenga $T$. Influenza and pneumococcal vaccination in long term care facilities in two regions of Quebec. Canadian Journal of Infectious Diseases 1996;7:296-300.

19. Patriarca PA, Weber JA, Meissner MK, Stricof RL, Dateno B, Braun JE, et al. Use of influenza vaccine in nursing homes. $J$ Am Geriatr Soc 1985;33:463-466.

20. Arden N, Monto AS, Ohmit SE. Vaccine use and the risk of outbreaks in a sample of nursing homes during an influenza epidemic. Am J Public Health 1995;85:399-401.

21. Kendal AP, Patriarca PA, Arden NH. Policies and outcomes for control of influenza among the elderly in the USA. Vaccine 1985;3(suppl):274-276.

22. Quick RE, Hoge CW, Hamilton DJ, Whitney CJ, Borges M, Kobayashi JM. Underutilization of pneumococcal vaccine in nursing homes in Washington State: report of a serotype-specific outbreak and a survey. Am J Med 1993;94:149-152.

23. Christie RW, Marquis LL. Immunization roulette: influenza occurrence in five nursing homes. Am I Infect Control 1985;13:174-177.

24. Canadian Long Term Care Association. Energy Survey of Long Term Health Care Facilities, Phase 1: Population Profile. Ottawa, Ontario, Canada: Energy Mines and Resources Canada; 1986.

25. Canadian Hospital Association. Directory of Long-Term Care Centres in Canada. Ottawa, Ontario, Canada: Canadian Hospital Association; 1990:9.

26. McGeer A, Campbell B, Emori TG, Hierholzer WJ, Jackson MM, Nicolle LE, et al. Definitions of infection for surveillance in long-term care facilities. Am J Infect Control 1991;19:1-7.

27. McArthur MA, Simor AE, Campbell B, McGeer A. Influenza and pneumococcal vaccination and tuberculin skin testing programs in long-term care facilities: where do we stand? Infect Control Hosp Epidemiol $1995 ; 16: 18-24$.

28. Watanakunakorn C, Ellis G, Gemmel D. Attitude of healthcare personnel regarding influenza immunization. Infect Control Hosp Epidemiol 1993;14:17-20.

29. Ballada D, Biasio LR, Cascio G, D'Alessandro D, Donatelli I, Fara GM, et al. Attitudes and behavior of health care personnel regarding influenza vaccination. Eur J Epidemiol 1994;10:63-68.

30. Nafziger DA, Herwaldt LA. Attitudes of internal medicine residents regarding influenza vaccination. Infect Control Hosp Epidemiol 1994;15:32-35.

31. Weingarten S, Riedinger M, Bolton LB, Miles P, Ault M. Barriers to influenza vaccine acceptance: a survey of physicians and nurses. $A m J$ Infect Control 1989;17:202-207.

32. Heimberger T, Chang HG, Shaikh M, Crotty L, Morse D, Birkhead G. Knowledge and attitudes of healthcare workers about influenza: why are they not getting vaccinated? Infect Control Hosp Epidemiol 1995;16:412-414.

33. Nichol KL, Hauge M. Influenza vaccination of healthcare workers, Infect Control Hosp Epidemiol 1997;18:189-194.

34. Patriarca PA, Arden NH, Koplan JP, Goodman RA. Prevention and control of type A influenza infections in nursing homes. Ann Intern Med 1987:107:732-740.

35. Sérié C, Barme M, Hannoun C, Thibon M, Beck H, Aquino JP. Effects of vaccination on an influenza epidemic in a geriatric hospital. Dev Biol Stand 1977;39:317-321.

\title{
Anthrax as a Biological Weapon: Medical and Public Health Management
}

\section{Gina Pugliese, RN, MS Martin S. Favero, PhD}

In a consensus statement published in the Journal of the American Medical Association, the Working Group on Civilian Biodefense asserts that the medical community requires training about anthrax in order to respond effectively in the event of a terrorist attack. The current US anthrax vaccine, which is made by Michigan's Bioport Corporation, is derived from the cell-free filtrate of a nonencapsulated attenuated strain of
Bacillus anthracis and requires six shots. The authors note that approximately 590,000 doses of the vaccine have been administered to US military personnel as of March 1, 1999, with no serious adverse effects. However, stocks and production of the vaccine are limited, and it could be several years until adequate quantities of vaccine are available for civilians. The working group notes, though, that "even if vaccine were available, populationwide vaccination would not be recommended at this time, given the costs and logistics of a large-scale vaccination program and the unlikely occurrence of a bioterrorist attack in any given community." Additional knowledge is also needed with regard to possible maximum incubation times after exposure to spore-containing aerosols and to the best postexposure drug treatments.

FROM: Inglesby TV, Henderson DA, Bartlett JG, Ascher MS, Eitzen E, Friedlander AM, et al. Anthrax as a biological weapon: medical and public health management. Working Group on Civilian Biodefense. JAMA 1999; 281:1735-1745. 